Scientific Research in U.S.A.

Is his report for 1933, the president of the Carnegie Institution of Washington has directed attention to the difficulties which beset scientific research during periods of political uncertainty and retrenchment. "Periods of emergency give rise to shifting conditions which may tend to press toward extinction of research and research institutions through financial weakening, and because of emphasis on what may be considered essentials of life." But on the other hand, emergencies present tests of adequacy in research as a method and of the human value of specific ideas for the origin of which it is responsible. The president says it is difficult to visualise a situation in which we could retreat from the present position. "The needs of civilisation can never be met by a static condition in which the generations merely settle down to life at a particular level. One can assume that through coming ages the requirement for increased knowledge with new ideas and their bettered application will grow. Unusual constructive ability arising out of what is known as the scientific interpretation will have an increasingly important part in development and organization of society. The investigation process, both as a means of securing ideas and as a method for learning their application, will naturally and properly take its place as one of the most nearly indispensable of all activities upon which the future well-being of mankind depends."

\section{Cave Exploration}

Now that the formation of $a_{\mathbf{b}}$ central body devoted to spelæological research in Great Britain holds out the prospect of a more systematic promotion of this branch of scientific studies, it is interesting to note the progress made in other countries towards the attainment of a like object. An article by M. R. de Joly, president of the Spéléo-Club de France, in La Nature of August 1 rapidly surveys recent activities in cave exploration, but touches in greater detail on the explorations in France of his own organisation. The Spéléo-Club de France was founded so recently as 1930, largely through the enthusiasm of M. E. A. de Martel ; but already its members have explored or visited no less than six hundred caves, mostly in the Basses-Alpes, and some presenting considerable difficulties of penetration and no little risk to the explorers. One of the most remarkable feats of cave exploration to which M. de Joly refers was that of the great cave at the foot of the Guadalupe Hills, New Mexico-an area of which the cave exploration is now attracting no little attention in archæological circles in the United States in connexion with the association there of early man with a fauna now extinct. The cave of which M. de Joly writes, although discovered in 1901, was not systematically attacked until 1930, when a subvention from the New York Times made possible the organisation of an expedition of fifteen members to spend a fortnight underground. Notwithstanding difficulties of passage, no less than $51 \mathrm{~km}$. were covered, including many chambers of enormous size. Another country which displays great activity in cave exploration is Italy, thanks to official financial support and the enthusiasm and friendly rivalry of a large number of local societies. Three thousand caves have been recorded as explored; and the Italians also hold the record for depth of descent. The Italian caves, indeed, are the deepest known, twelve being more than $250 \mathrm{~m}$. deep, and four more than $300 \mathrm{~m}$., while the deepest of all, the Bus della Preta, near Verona, has a depth of $620 \mathrm{~m}$.

\section{The Rabbit Menace}

WILD rabbits have become so numerous in many parts of England that considerable alarm has been expressed by farmers and in the public press at the damage done to crops, pastures and young trees. The University of London Animal Welfare Society has for some years made a special study of the subject. It has now taken a useful and timely step in reprinting in Great Britain, by permission of the New South Wales authorities, a brochure entitled "The Rabbit Menace in Australia in 1933 and the Way Out", by David G. Stead, formerly special rabbit menace commissioner to the Govern. ment of New South Wales. The booklet brings strong confirmation to the views previously promulgated by the Society to the effect that the wild rabbit, considered as stock, does not pay, since the damage done by it far exceeds the price received by the farmer; that the trapping industry increases the stock of rabbits instead of diminishing it, and that control of the rabbit-population can be most efficiently (as well as most humanely) carried out by the use of calcium cyanide or similar products yielding hydrocyanic acid gas. The Society has issued several other publications on the subject of rabbit-control.

\section{Treatment of Anæmias}

We have received from Boots Pure Drug Co., Ltd., Nottingham, an illustrated booklet describing the different products issued by this firm for the treat ment of the anæmias. 'Pepsac' is an active preparation of desiccated hog's stomach, which is given by mouth in pernicious anæmia: 'Hepostab' is an extract of liver specially prepared for intramuscular injection. It is suggested that treatment be commenced with 'Hepostab', especially if the case is a severe one, and continued from the fourth day onwards with 'Pepsac'. Each batch of 'Hepostab' is subjected to clinical trial before issue. Both preparations, and especially 'Pepsac', are of great value in the treatment of subacute combined degeneration of the spinal cord, the most severe complication of pernicious anæmia. Messrs. Boots also prepare liver extracts for oral administration, namely, compound fluid extract of liver-Boots, liquid extract of liver B.P., and dry extract of liver -Boots. For the treatment of secondary anæmias, 'Livron' is recommended: this is an extract of liver, yeast and malt with the addition of a full therapeutic dose of iron.

\section{Medical Research in Egypt}

WE have received the third annual report of the Research Institute and the Endemic Diseases 
Hospital, Cairo, for the year 1933. This shows that, under the directorship of Dr. M. Khalil Bey, much valuable work is being done on the endemic diseases and epidemiology of Egypt. One of the most interesting announcements is the discovery of the intermediate host of a human trematode or 'fluke' parasite, Heterophyes heterophyes, first discovered in 1851. The second intermediate host is a fish, in which the cysts of the metacercariæ were found in 1923, and from eating which human infection is derived. The first intermediate host has now been determined, and proves to be a fresh-water snail, Pirenella conica, which was found to be infected with the cercariæ of the parasite, and by eating this infected snail the fish become infected.

\section{Lectures on the Rothamsted Experiments}

DURING the forthcoming winter, Mr. H. V. Garner, the guide demonstrator of the Rothamsted Experimental Station, and other members of the staff are prepared to give lectures to chambers of agriculture and horticulture, agricultural societies, etc., on the Rothansted experiments. No fee will be charged for the lecturers' services but any association engaging them will be expected to defray their travelling and hotel expenses and to make such arrangements for the lecturers as may be necessary. The following topics are offered by the member of staff indicated : soil micro-organisms (Dr. H. G. Thornton, Dr. Hugh Nicol and Mr. D. W. Cutler), agricultural botany (Dr. Winifred Brenchley), agricultural chemistry (Dr. E. M. Crowther and Dr. H. L. Richardson), soil physics (Dr. B. A. Keen and Dr. R. K. Schofield), entomology (Dr. C. B. Williams, Dr. H. F. Barnes and Mr. D. M. T. Morland), plant pathology (Dr. J. Henderson Smith, Miss M. D. Glynne and Mr. Geoffrey Samuel), fertilisers, manures, etc. (Mr. H. V. Garner). Further information can be obtained from the Secretary, Rothamsted Experimental Station, Harpenden, Herts.

\section{Announcements}

THE late Prof. Ramon y Cajal has left a legacy of 25,000 pesetas to the Spanish Academy of Medicine to found a prize for the best work on a subject to be selected by the Academy.

THE Rockefeller Foundation has made the University of Chicago a donation of 243,000 dollars, of which 168,000 are to be spent on the foundation of a psychiatric clinic.

THE following appointments have been made by the Secretary of State for the Colonies: Mr. J. H. Harris, to be assistant chemist, Geological Survey, Tanganyika; Mr. C. W. S. Hartley, to be agricultural officer, Malaya ; Mr. G. B. Masefield, to be agricultural officer, Uganda; Mr. A. F. McKenzie, to be agricultural officer, Sierra Leone; Mr. R. F. A. L. Reed, to be superintendent of agriculture, Nigeria; Mr. W. T. Dalgarno, agricultural instructor, Bahamas, to be superintendent of agriculture, Nigeria; and Mr. E. Williams, superintendent of agriculture, Gambia, to be agricultural officer, Uganda.
THE annual exhibition of the Royal Photographic Society will be formally opened by the president, Mr. Robert Chalmers, on September 13. The exhibition will be open to the public in the Society's galleries, 35, Russell Square, W.C.1, on September 14 -October 12, from 10 a.m. until 9 p.m. (Sundays excepted), except Tuesdays and Fridays when it will be closed at 6 p.m., and lectures given. Admission to the exhibition is free.

The twenty-second Congress of the Alliance of Social Hygiene will be held in Angers on October 4-6, when the following subjects among others will be discussed: Social medicine and traditional family medicine, extension of the work of social hygiene in rural areas, social value of open-air sports, anticancer and anti-venereal disease centres, the campaign against tuberculosis, old-age assistance and the declining birth-rate. Further information can be obtained from Prof. C. Metzger, 36 Boulevard Ayrault, Angers.

Applicatrons are invited for the following appointments, on or before the dates mentioned:

An assistant director of works in the Egyptian Irrigation Service in the Sudan - The Chief Inspecting Engineer, Egyptian Government, 41, Tothill Street, London, S.W.1 (Sept. 16).

A head of the Mechanical Engineering Department of the School of Engineering and Navigation, High Street, Poplar, E.14 The Education Officer (T.1), County Hall, S.E.1 (Sept. 16).

An examiner in the Aeronautical Inspection Directorate-The Secretary (S.2.d.), Air Ministry, Kingsway, W.2 (Sept. 19).

A head of the Chemistry and Natural Science Department and Vice-Principal of the Portsmouth Municipal College-The Registrar (Sept. 21).

A research assistant in physics in the University of Leeds-The Registrar (Sept. 23).

An advisory economist in the Seale-Hayne Agricultural College, Newton Abbot, Devon-The Principal (Sept. 25).

An assistant lecturer in mathematics in the Royal College of Science-The Secretary, Imperial College of Science and Technology, Prince Consort Road, South Kensington, S.W.7 (Oct. 1).

Two assistants in cancer research-The Secretary, British Empire Cancer Campaign, 12 Grosvenor Crescent, London, S.W.1.

A lecturer in structural engineering and mechanics in the Borough Polytechnic, Borough Road, London, S.E.1-The Principal.

Part-time lecturers in automobile engineering, theory, practice, drawing and design in the Polytechnic, Regent Street, W.1-The Director.

An assistant lecturer and demonstrator in the Faraday House Electrical Engineering College-The Principal, Faraday House, W.C.l. 